CAD/CAM

sistemiyle hazırlanan üç

üyeli monolitik

zirkonya ve zirkonyum

destekli restorasyonların

FDI kriterlerine göre

değerlendirilmesi:

Bir yıllık klinik

split-mouth çalışması

\section{Evaluation of three-unit monolithic zirconia and zirconia-supported fixed partial dentures designed with CAD/CAM system by FDI criteria: A one year clinical split-mouth study}

\author{
Dt. Elçin Keskin Özyer \\ Marmara Üniversitesi, Diş Hekimliği Fakültesi, \\ Protetik Diş Tedavisi A.D., İstanbul \\ Orcid ID: 0000-0002-8826-024X \\ Dr. Öğr. Üyesi Erkut Kahramanoğlu \\ Marmara Üniversitesi, Diş Hekimliği Fakültesi, \\ Protetik Diş Tedavisi A.D., İstanbul \\ Orcid ID: 0000-0002-2583-6627 \\ Prof. Dr. Yasemin Kulak Özkan \\ Marmara Üniversitesi, Diş Hekimliği Fakültesi, \\ Protetik Diş Tedavisi A.D., İstanbul \\ Orcid ID: 0000-0002-4699-638X
}

Geliş tarihi: 20 Kasım 2019

Kabul tarihi: 25 Kasım 2019

doi: 10.5505/yeditepe.2020.78557

\footnotetext{
Yazışma adresi:

Dr. Öğr. Üyesi Erkut Kahramanoğlu

Marmara Üniversitesi, Diş Hekimliği Fakültesi

Protetik Diş Tedavisi A.D. Başıbüyük Cad. No: 9/3

34854 istanbul-Türkiye

Bağdat Cad. No:238 34728 İstanbul

Tel: :+905334102900

E-posta: erkut.kahramanoglu@marmara.edu.tr
}

\section{ÖZET}

Amaç: Bu in vivo çalışmanın amacı, posterior bölgedeki 3 üyeli zirkonyum destekli ve monolitik zirkonya restorasyonların klinik başarısını değerlendirmektir.

Gereç ve Yöntem: Çalışmamıza, simetrik (split-mouth) alt çene birinci molar eksikliği olan 3 üyeli sabit protetik tedavi gereksinimli 20 katılımcı dahil edilmiştir. Hastalara CAD/CAM kullanılarak toplam 40 adet köprü restorasyonu (20 adet monolitik zirkonya restorasyon (Zenostar T) ve 20 adet zirkonyum destekli restorasyonların altyapıları (IPS e.max ZirCAD)) üretilmiştir. Üstyapı veneer seramiği (IPS e.max Ceram) ile tabakalama tekniği kullanılarak zirkonyum destekli restorasyonların üretimi tamamlanmıştır. Klinik değerlendirmeleri 1. hafta, 6 . ay ve 1. yılda FDI kriterleri kullanılarak yapıldı. İstatistiksel analiz için "Friedman" ve "Wilcoxon" testi kullanılmıştır.

Bulgular: Elde edilen verilere göre çift tabakalı ve monolitik restorasyonlarda estetik kriterlerden "yüzey parlaklı̆ıı", "yüzeyel ve marjinal renklenme", "renk uyumu ve translusensi", "estetik ve anatomik form" değerlerinde zaman içerisinde istatistiksel olarak anlamlı bir fark gözlenmemiştir $(p>0,05)$. Çalışmamızda, FDI'in fonksiyonel ve biyolojik kriterleri için elde edilen veriler çift tabakalı ve monolitik restorasyonlar için istatistiksel olarak anlamlı bulunmamıştır $(p>0,05)$.

Sonuç: FDI kriterleri kullanılarak yapılan incelemelerde "renk uyumu ve translusensi" değerlendirmelerinde zirkonyum destekli restorasyonların; "estetik ve anatomik form" değerlendirmelerinde monolitik zirkonya restorasyonların daha başarılı sonuçlar verdiği görülmüştür. Çalışmamızda, zirkonya restorasyonların 1 yıllık klinik takibinde başarı oranı \%100 olarak belirlenmiştir.

Anahtar kelimeler: CAD/CAM, klinik başarı, monolitik zirkonya, FDI kriterleri.

\section{SUMMARY}

Aim: The aim of this in vivo study was performed to evaluate and compare clinical success of 3-unit zirconia-supported and monolithic zirconia restorations in the posterior region.

Materials and Methods: Twenty patients who required three-unit fixed partial dentures due to a missing first molar in both half jaws (split-mouth design) were included in this in vivo study. A total of 40 bridge restorations (20 restorations were monolithic zirconia (Zenostar T), and the framework of 20 were zirconia-supported restorations (IPS e.max ZirCAD)) were fabricated with CAD/CAM technology. Zirconia-supported restorations built with superstructure by hand-layering technique with veneering ceramic (IPS e.max Ceram). Clinical evaluations were made at 1. week, 6. months and 1. year using FDI criteria. Statistical analysis was performed using "Friedman" and "Wilcoxon" tests were used.

Results: There was no statistically significant difference within the double-layer and monolithic restoration groups for aesthetic criteria ("Surface brightness", "Superficial and marginal staining", "Color matching and translucency", "Aesthetic and anatomical form") depending on time $(p>0,05)$. The data 
obtained from this study according to the functional and biological criteria of FDI were not statistically significant for double-layer and monolithic restorations $(p>0,05)$.

Conclusion: According to the criteria of FDI, the zirconium supported restorations were found to be more successful in "Color matching and translucency" and monolithic zirconia restorations were found to be more successful in "Aesthetic and anatomical form" evaluation. In the present study, the success rate was determined as $100 \%$ in 1-year clinical follow-up of zirconia restorations.

Keywords: CAD/CAM, clinical success, monolithic zirconia, FDI criteria

\section{Gíriș}

\subsection{Zirkonyum Destekli Restorasyonlar}

Zirkonyum ilk olarak 1789 yılında Alman kimyacı Martin Heinrich Klaproth tarafından, birtakım değerli taşların ısıtılması sonucu reaksiyon ürünü olarak bulunmuştur. ${ }^{1}$ 1990'ların başında diş hekimliğinde kullanılmaya başlanmıştır. Klinikte kor materyali olarak kullanımı; tatminkâr optik özellikler, 1000 MPa'ı geçen yüksek bükülme direnci, biyolojik uyumluluğu ve translusent olması gibi avantajları nedeniyle metal altyapılı sistemlere alternatif olarak güçlendirimiş tam seramik sistemleri arasında sıklıkla tercih edilmektedir. ${ }^{2,3}$

Yyttrium ile stabilize edilmiş (\%2-3 mol) zirkonyum (Y-TZP) materyali yüksek dayanım, kırıma tokluğu, sertlik, aşınmaya karşı direnç, biyouyumluluk, düşük termal iletkenlik, asit ve alkali içinde korozyona direnç, çeliğe benzer elastiklik modülü gibi özellikleri sayesinde yaygın olarak kullanılmaktadır. ${ }^{2,3}$ Ancak opak beyaz renkte olduğu için uzun süre feldspatik porselenlerle veneerlenerek altyapı materyali olarak kullanılmıştır. ${ }^{3}$

Yapılan çalışmalarda zirkonyum destekli restorasyonlar için karşılaşılan en büyük sorunun, üstyapı seramiği ve zirkonya materyalleri arasındaki termal ekspansiyon katsayıları uyumsuzluğuna bağlı olarak chipping, yüzeyel porselen ayrilmaları ve veneer porselende meydana gelen kohesiv porselen kırıkları olduğunu göstermiştir., ${ }^{4,5}$ Bu durum veneerleme prosedürüne intiyaç duyulmadan anatomik konturlu olarak hazırlanan restorasyonların arayışını gerektirmiştir. Günümüzde zirkonyum oksit içerikli restoratif materyallerin ve CAD/CAM sistemlerinin gelişmesiyle altyapısız, anatomik konturlu monolitik zirkonya restorasyonlar üretilebilmektedir. ${ }^{5,6}$

\subsection{Monolitik Zirkonya Restorasyonlar}

"Mono" kelimesi Yunanca'daki "tek"; "litik" kelimesi ise "taş" anlamına gelen karşılıklarından köken alır. Günümüzde "bütünün tamamını tek materyalle oluşturan" restorasyonları ifade etmek için kullandığımız "monolitik" kelimesinin doğrudan karşıı̆ının "tek taş" olduğu söylenebilir. Böyle restorasyonlar için "monoblok" terimi de yaygın olarak kullanılmaktadır. ${ }^{6}$

Monolitik zirkonya restorasyonlar; bükülme direnci (1570
Mpa), elastik modülüsü $(113,1 \mathrm{GPa})$ ve ısı dayanımının $\left(2600^{\circ} \mathrm{C}\right)$ yüksek olması, yüksek biyouyumluluğa sahip olması, opasitelerinin azaltılması ile estetik özelliklerinin geliştirilmesi, özel boyama solüsyonları kullanılarak renklendirilebilmesi, interokluzal mesafenin yetersiz olduğu vakalarda kullanılabilmesi, antagonist dişte minimum aşınma meydana getirmesi gibi avantajları sebebiyle tercih edilmektedir. ${ }^{5-7}$

Monolitik zirkonya restorasyonların; zirkonyum destekli, monolitik lityum disilikat ve metal seramik restorasyonlara göre daha yüksek dayanıklıık gösterdiği bildirilmiştir., Yapılan çalışmalarda, monolitik zirkonya restorasyonların kırılma dayanıklıığının en yüksek olduğu materyal kalınlığının 0,6-1,5 mm arası olduğu bildirilmiştir. ${ }^{8}$

Monolitik zirkonya yüzeyleri hem cilalama hem de glazeleme işlemi ile 2 farklı şekilde hazırlanabilmektedir. ${ }^{9} \mathrm{Ci}$ lalama işlemi için; aşındırıcı patlar, elmas frezler ve lastik diskler kullanılırken, glazeleme işleminde yüzey ince bir cam tabakası ile kaplanarak uygun ısıda fırınlanmaktadır. ${ }^{5}$

\subsection{Klinik Değerlendirme ve Başarı Kriterleri}

Cvar ve Ryge, 1971 yılında restorasyonların klinik başarısının değerlendirilmesinde United States Public Health Service (USPHS) kriterlerini geliştirmişlerdir. ${ }^{10}$ Restorasyonların komşu diş ve/veya restorasyonlarla olan renk uyumlarına, restorasyonların bitim sınırlarında renklenmenin olup olmadığına, restorasyonların anatomik formlarının devamlılığına, bitim sınırındaki adaptasyonlarına ve sekonder çürük olup olmadığına göre restorasyonların değerlendirmeleri yapılır. Tüm bu veriler sonucunda restorasyonların, klinik olarak kabul edilebilir olup (Ideal restorasyonlar Alfa; kabul edilebilir restorasyonlar Bravo); olmadığına (Değiştirilmesi gereken restorasyonlar Charlie; hemen değiştirilmesi gereken restorasyonlar Delta) karar verilir.1" USPHS sistemi, restorasyonların kalitesi değerlendirilirken başarının derecesinden çok, restorasyonun kabul edilebilirliğini belirleyecek şekilde hazırlanmıştır. Anatomik form, marjinal adaptasyon ve marjinal renklenme gibi değerlendirme kriterlerinde meydana gelen değişiklikleri belirlemede yetersiz olduğu için Modifiye USPHS ya da Ryge kriterleri kullanılmaya başlanmıştır. Modifiye USPHS değerlendirmelerine yüzey pürüzlülüğü, diş bütünlüğü, restorasyon bütünlüğü, retansiyon ve postoperatif hassasiyet kriterleri de katılmıştır. ${ }^{11}$

Klinik değerlendirmelerde sıklıkla kullanılan bir diğer sistem ise 1973 yılında California Dental Association'ın (CDA) geliştirdiği sistemdir. Bu sistem iki bölüme ayrılmış olup marjinal bütünlük, anatomik form, renk ve yüzey değerlendirilmesinde geçerli olan ayrıntıları "klinik olarak kabul edilebilir" ya da "klinik olarak kabul edilemez" olarak belirtilirler. Her iki temel grupta ikişer alt grup içermektedir. ${ }^{12}$ 2007 yılında restorasyonların klinik değerlendirmesinde FDI (World Dental Federation)'ın onayladığı yeni klinik kriterler kullanılmaya başlanmıştır. Bu kriterlere "FDI klinik 
değerlendirme kriterleri" ismi verilmiştir. FDI kriterlerinde restorasyonlar estetik (Tablo 1), fonksiyonel (Tablo 2 ) ve biyolojik (Tablo 3) olmak üzere üç farklı kategoride değerlendirilmektedir. ${ }^{13}$

Tablo 1. FDI estetik klinik değerlendirme kriterleri

\begin{tabular}{|c|c|c|c|c|}
\hline $\begin{array}{c}\text { A. ESTETIK } \\
\text { PROTETIK REST. }\end{array}$ & $\begin{array}{c}\text { 1. YÜZEY } \\
\text { PARLAKLIGI }\end{array}$ & $\begin{array}{l}\text { 2. YÜZEYEL/ } \\
\text { MARJINAL } \\
\text { RENKLENME }\end{array}$ & $\begin{array}{l}\text { 3. RENK UYUMU } \\
\text { VE } \\
\text { TRANSLUSENSİ }\end{array}$ & $\begin{array}{c}\text { 4. ESTETIK } \\
\text { ANATOMIK FORM }\end{array}$ \\
\hline $\begin{array}{l}\text { 1. KLÍNIKK } \\
\text { OLARAK COK IYI }\end{array}$ & $\begin{array}{l}1.1 \text { Mineye benzer } \\
\text { parlakllik }\end{array}$ & $\begin{array}{l}2 \text { 2.1Y Yüzey } \\
\text { renklenmesi yok } \\
\text { 2b.1. Kenar } \\
\text { renklenmesi yok }\end{array}$ & $\begin{array}{l}3.1 \text { fyi renk eşleme, } \\
\text { renk tonu ve } \\
\text { translusensisinde fark } \\
\text { yok }\end{array}$ & 4.1 fdeal form \\
\hline $\begin{array}{l}\text { 2. KLINNIK } \\
\text { OLARAK IYI } \\
\text { (PARLATMA } \\
\text { SONRASI ÇOK İẎ) }\end{array}$ & $\begin{array}{l}1.2 .1 \text { Hafif mat, } \\
\text { konuşma } \\
\text { mesafesinden fark } \\
\text { edilebiliri değil } \\
\text { 1.2.2. Izole }\end{array}$ & $\begin{array}{l}\text { 2a.2 Minör yüzey } \\
\text { renklenmesi, parlatma } \\
\text { ile kolay gider ilebilir. } \\
\text { 2b.2. Parlatma ile } \\
\text { kolay giderilebilir, } \\
\text { minoôr marjinal }\end{array}$ & $\begin{array}{l}3.2 \text { Renk tonu ve/ } \\
\text { veya translusenside } \\
\text { minör değişiklikler }\end{array}$ & $\begin{array}{l}4.2 \text { Normal formdan } \\
\text { hafif farklı }\end{array}$ \\
\hline $\begin{array}{l}\text { 3. KLİNIK } \\
\text { OLARAK } \\
\text { YETERLİ (MİNÖR } \\
\text { ASINMA; DİSE } \\
\text { ZARAR VEREN VE } \\
\text { KABUL } \\
\text { EDİLEMEYEN BİR } \\
\text { SONUÇ YOK) }\end{array}$ & $\begin{array}{l}\text { 1.3.1 Tüküriikle } \\
\text { kaplandı̆̆ngda kabul } \\
\text { edilebilir mat yüzey } \\
\text { 1.3.2. Yüzeyin 1/3 } \\
\text { ünden fazlasında } \\
\text { coklu gözenekler }\end{array}$ & $\begin{array}{l}\text { 2a.3 } 3 \text { Estetik olarak } \\
\text { kabul edilebilir, diğgr } \\
\text { dişlerde de olabilen } \\
\text { orta derecede yüzey } \\
\text { renklenmesi } \\
\text { 2b.3 Estetik olarak } \\
\text { kabul edilebilir, orta } \\
\text { derecede yüzey } \\
\text { renklenmesi }\end{array}$ & $\begin{array}{l}\text { 3.3 Kabul edilebilir, } \\
\text { estetiği etkilenmemiş } \\
\text { bariz değisisik } \\
\text { 3.3.1 daha opak } \\
\text { 3.3.2 daha tranlusent } \\
\text { 3.3.3 daha karanlık } \\
\text { 3.3.4 daha aydınlkk }\end{array}$ & $\begin{array}{l}4.3 \text { Estetik olarak } \\
\text { kabul edilebilir, } \\
\text { normal formdan } \\
\text { sapma }\end{array}$ \\
\hline $\begin{array}{l}\text { 4. KLINIK } \\
\text { OLARAK } \\
\text { YETERSIZ (TAMIR } \\
\text { EDILEBILIR) }\end{array}$ & $\begin{array}{l}\text { 1.4.1 Pürüzlü yüzey, } \\
\text { parlatma ve tükürük } \\
\text { ile maskeleme yeterli } \\
\text { değil. Illeri müdahale } \\
\text { gerekli } \\
1.4 .2 \text { Geçersiz }\end{array}$ & $\begin{array}{l}\text { 2a.4 Restorasyon } \\
\text { üzerinde kabul } \\
\text { edilemeyen yüzey } \\
\text { renklenmesi, ileri } \\
\text { girişim gerekli } \\
\text { 2b.4 Belirgin bitim } \\
\text { çizgisinde renklenme, } \\
\text { ileri girişim gerekli }\end{array}$ & $\begin{array}{l}\text { 3.4 Tamir edilebilir, } \\
\text { lokalize klinik } \\
\text { değģşiklik } \\
\text { 3.4.1. çok opak } \\
\text { 3.4.2. çok translusent } \\
\text { 3.4.3. çok karanlık } \\
\text { 3.4.4. çok aydınlık }\end{array}$ & $\begin{array}{l}\text { 4.4 Eșettik olarak } \\
\text { kabul edilmeyen } \\
\text { etkilenmiş form. } \\
\text { Girişim/düzeltme } \\
\text { gerckli }\end{array}$ \\
\hline $\begin{array}{l}\text { 5. KLIINIK } \\
\text { OLARAK } \\
\text { BASARISIZ } \\
\text { (YENILEME } \\
\text { GEREKLI) }\end{array}$ & $\begin{array}{l}1.5 \text { Çok pürūzlä } \\
\text { yüzey, plak } \\
\text { retansiyonu ile kabul } \\
\text { edilebilir değil }\end{array}$ & $\begin{array}{l}\text { 2a.5 Genteralize yada } \\
\text { lokalize, ciddi yüzey } \\
\text { ve yüzey altı } \\
\text { renklenme, girişim } \\
\text { yeterli değil }\end{array}$ & $\begin{array}{l}3.5 \text { Kabul edilemez. } \\
\text { Yenileme gerekli }\end{array}$ & $\begin{array}{l}\text { 4.5 Bozulmus form, } \\
\text { tamir yetersiz. } \\
\text { Yenileme gerekli }\end{array}$ \\
\hline
\end{tabular}

Tablo 2. FDI fonksiyonel klinik değerlendirme kriterleri.

\begin{tabular}{|c|c|c|c|c|c|c|}
\hline $\begin{array}{c}\text { B. } \\
\text { FONKSIYONEL } \\
\text { ÖZELLLiKLER }\end{array}$ & $\begin{array}{c}5 . \\
\text { RETANSIYON } \\
\text { VE } \\
\text { MATERYAL } \\
\text { KIRIĞI }\end{array}$ & $\begin{array}{c}6 . \\
\text { MARJINAL } \\
\text { ADAPTASYON }\end{array}$ & $\begin{array}{c}7 . \\
\text { OKLUZAL } \\
\text { KONTUR VE } \\
\text { YIPRANMA }\end{array}$ & $\begin{array}{c}8 . \\
\text { APROKSIMAL } \\
\text { ANATOMIK } \\
\text { FORM } \\
\text { a TEMAS } \\
\text { NOKTASI } \\
\text { b. KONTÜR }\end{array}$ & $\begin{array}{c}9 . \\
\text { RADYOGRAFIK } \\
\text { DEGERLENDiR } \\
\text { ME }\end{array}$ & $\begin{array}{l}\text { 10. HASTA } \\
\text { MEMnUNIYY } \\
\text { ETi }\end{array}$ \\
\hline $\begin{array}{c}\text { 1. KLiNiK } \\
\text { oLARAK ÇOK } \\
\text { IYI }\end{array}$ & $\begin{array}{c}5.1 \text { Krikk ve } \\
\text { cattak yok }\end{array}$ & $\begin{array}{l}6.1 \text { Uyumlu } \\
\text { görünüm; } \\
\text { aralanma, beyaz } \\
\text { hat ve renkte } \\
\text { bozulma yok }\end{array}$ & $\begin{array}{c}\text { 7a.1 Mineye } \\
\text { esdeğer fiziksel } \\
\text { yppranma } \\
\text { 7b.1 Minemin 80- } \\
\% \text { \%120 sine oranla } \\
\text { yipranma }\end{array}$ & $\begin{array}{c}\text { 8a. } 1 \text { Normal } \\
\text { termas (diș ipi } \\
\text { yada } 25 \mu \mathrm{mm} \\
\text { metal bant } \\
\text { gecsebiliti.) } \\
\text { 8b.1 Normal } \\
\text { kontur }\end{array}$ & $\begin{array}{c}\text { 9.1 Patoloji yols, } \\
\text { restorasyon ile dis } \\
\text { arasnda uyumlu } \\
\text { gecis }\end{array}$ & $\begin{array}{c}10.1 \text { Estetik ve } \\
\text { fonksiyonel } \\
\text { olarak tam } \\
\text { kabul edilebilir }\end{array}$ \\
\hline $\begin{array}{l}\text { 2. KLIINIK } \\
\text { OLARAK IYI }\end{array}$ & $\begin{array}{c}5.2 \text { Kǖ̧̧iki ince } \\
\text { șizgi halinde } \\
\text { ayrıma }\end{array}$ & 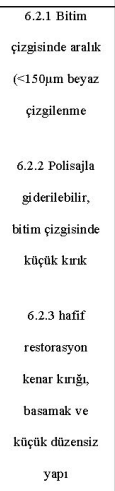 & $\begin{array}{c}\text { 7a.2 Mineden } \\
\text { hafif farklı } \\
\text { yipranma } \\
\text { 7b.2 Mineye } \\
\text { oranla \% \% } 0 \text {-80 } \\
\text { ya da \%120-150 } \\
\text { y1pranma }\end{array}$ & 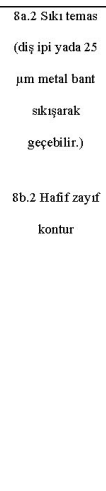 & 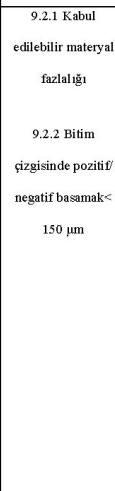 & $\begin{array}{c}10.2 \text { Yeterli } \\
10.2 .1 \text { Estetik } \\
10.2 .2 \\
\text { Fonksiyonel } \\
\text { örn. kü̧üilk } \\
\text { matlaşma }\end{array}$ \\
\hline $\begin{array}{c}\text { 3. KLİNIK } \\
\text { OLARAK } \\
\text { YETERLi } \\
\text { (KËÇC̄KK } \\
\text { NOKSANLIK; } \\
\text { DISSE ZARARAR } \\
\text { VEREN VE } \\
\text { KABUL }\end{array}$ & 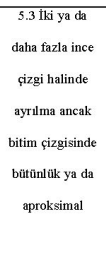 & 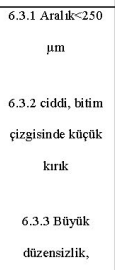 & $\begin{array}{c}\text { 7a.3 Biyolojik } \\
\text { sunular içinde } \\
\text { mineden farkl1 } \\
\text { yipranma } \\
\text { 7b.3 Mineye } \\
\text { oranla }<\text { <\%50 ya }\end{array}$ & $\begin{array}{l}\text { 8..3 Hafif zayyf } \\
\text { temas, diş, } \\
\text { gingiva ve } \\
\text { periodontal } \\
\text { yapilarda hasar } \\
\text { yok. } 50 \text { um metal } \\
\text { zumpara } \\
\text { geçebilit. }\end{array}$ & $\begin{array}{c}9.3 .1 \text { Bitim } \\
\text { çizgisinde aralks= } \\
250 \mu \mathrm{mm} \\
9.3 .2 \mathrm{Negatif} \\
\text { basamak } 250 \text { um }\end{array}$ & 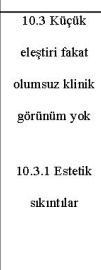 \\
\hline $\begin{array}{c}\text { EDiLEMEYEN } \\
\text { Bir SONUÇ YOK) }\end{array}$ & $\begin{array}{c}\text { temasta } \\
\text { etkilenme yok }\end{array}$ & $\begin{array}{c}\text { basananak ya da } \\
\text { kenar kinğ́ı }\end{array}$ & $\begin{array}{c}\text { da \%al } 150-300 \\
\text { yypranma }\end{array}$ & $\begin{array}{c}\text { 8b.3 Gö̀rininir } \\
\text { zayif temas }\end{array}$ & & \begin{tabular}{|c}
10.3 .2 Çiğneme \\
ile ilgigli \\
sklintlar \\
\\
10.3 .3 \\
Memnuniyetsiz \\
tedavi \\
prosedürù
\end{tabular} \\
\hline $\begin{array}{l}\text { 4. KLININIK } \\
\text { OLARAK } \\
\text { YETERSiz } \\
\text { (TAMIR } \\
\text { EDLLEBILIR) }\end{array}$ & 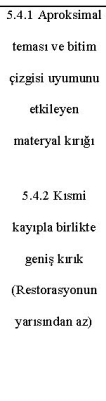 & 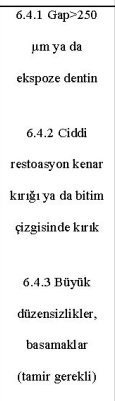 & 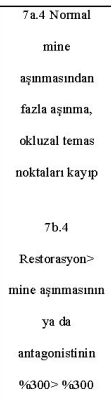 & 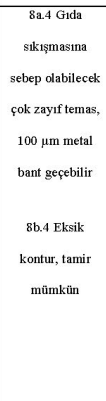 & 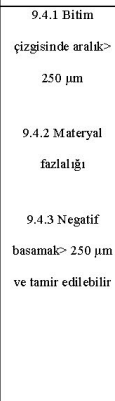 & 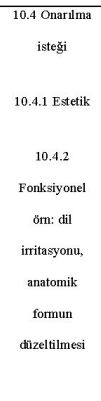 \\
\hline $\begin{array}{c}\text { 5. KLINIKK } \\
\text { OLARAK } \\
\text { BASARISIZ } \\
\text { (YENILEME } \\
\text { GEREKLI) }\end{array}$ & $\begin{array}{c}5.5 \\
\text { Restorasyonun } \\
\text { kısmi ya da tüm } \\
\text { kaybi ya da } \\
\text { multiple krrik }\end{array}$ & 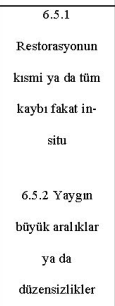 & 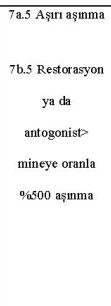 & 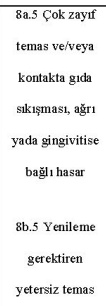 & 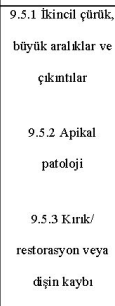 & $\begin{array}{l}10.5 \text { Tamamı } \\
\text { ile tatmin } \\
\text { etmeyen ve } \\
\text { fveya ters tepki, } \\
\text { ağrn gibi }\end{array}$ \\
\hline
\end{tabular}


Tablo 3. FDI biyolojik klinik değerlendirme kriterleri

\begin{tabular}{|c|c|c|c|c|c|c|}
\hline 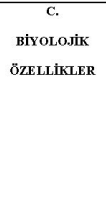 & $\begin{array}{c}\text { 11. } \\
\text { POSTOPERATÍ } \\
\text { F HASSASIYKT } \\
\text { VE dís } \\
\text { vitALítESí }\end{array}$ & $\begin{array}{c}\mathbf{1 2 .} \\
\text { Ç̈̈RT̈K } \\
\text { TEKRARI, } \\
\text { EROZYON, } \\
\text { ABFRAKSIYON }\end{array}$ & $\begin{array}{c}13 . \\
\text { Diş } \\
\text { BÜTÜNLÜ̈GU } \\
\text { (MINE Dis } \\
\text { KTRIKLARI) }\end{array}$ & $\begin{array}{c}14 . \\
\text { PERTODONTAL } \\
\text { CEVAP } \\
\text { (REFERANS } \\
\text { DișLE } \\
\text { KARSILASTIRI } \\
\text { ARAK) }\end{array}$ & $\begin{array}{c}15 . \\
\text { KOMŞU } \\
\text { MUKOZA }\end{array}$ & $\begin{array}{c}\text { 16. ORAL VE } \\
\text { GENEL SAGLLKK } \\
\text { DURIMU }\end{array}$ \\
\hline $\begin{array}{c}\text { 1. KLİíiK } \\
\text { OLARAK ÇOK } \\
\text { ixí }\end{array}$ & $\begin{array}{c}11.1 \text { Hassaiyyct } \\
\text { yok, normal } \\
\text { vitalite }\end{array}$ & $\begin{array}{l}12.1 \text { ikincil ya da } \\
\text { birincil quürik yok }\end{array}$ & $\begin{array}{l}\text { 13.1. Tannamu ile } \\
\text { bütünläk }\end{array}$ & $\begin{array}{c}\text { 14.1. Plaks, } \\
\text { enflamasyon ve ecp } \\
\text { yok }\end{array}$ & $\begin{array}{c}15.1 \text { Sağ́lkktı } \\
\text { mukoza }\end{array}$ & $\begin{array}{l}16.1 \text { Oral ve gencl } \\
\text { semptom yok }\end{array}$ \\
\hline $\begin{array}{c}\text { 2. KLINIK } \\
\text { OLARAK IYi } \\
\text { (DÜZELTME } \\
\text { SORASI çOK } \\
\text { INT) TEDAVIt } \\
\text { IHTIYACI YOK }\end{array}$ & $\begin{array}{c}11.2 \text { Strurth bir } \\
\text { sure icinin az } \\
\text { hassasiyct, normal } \\
\text { vitalitc }\end{array}$ & $\begin{array}{c}12.2 \text { Kụ̈utik ve } \\
\text { lokalize } \\
\text { 1.demineralizasyo } \\
n \\
\text { 2.erozyon } \\
\text { 3.abfraksiyon }\end{array}$ & 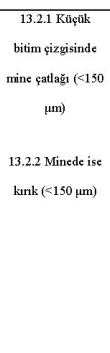 & 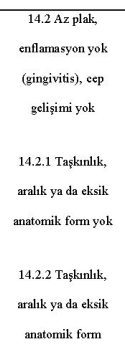 & 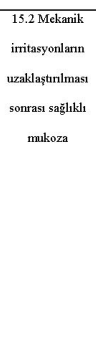 & $\begin{array}{l}16.2 \text { Minór lasa } \\
\text { surrcli snnrth/yaygn } \\
\text { semptom }\end{array}$ \\
\hline 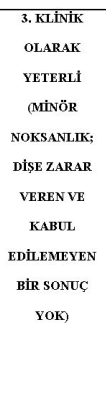 & 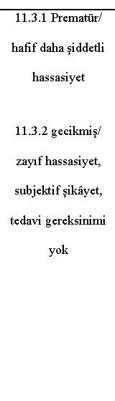 & 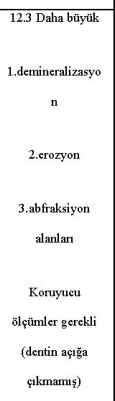 & 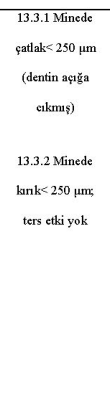 & $\begin{array}{c}\text { 14.3.1 Kabul } \\
\text { cdilicbilib plak } \\
\text { birilimi } \\
14.3 .2 \text { Kabul } \\
\text { edilcbilir dị cti } \\
\text { kanaması } \\
14.3 .3 \text { Kabul } \\
\text { edilebilir eep varlığ }\end{array}$ & 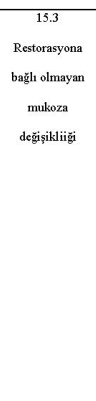 & $\begin{array}{l}16.3 \text { Kisa surrcli } \\
\text { snurl/ yaygen } \\
\text { semptom }\end{array}$ \\
\hline $\begin{array}{c}\text { 4. KLiNiK } \\
\text { OLARAK } \\
\text { YETERSiz } \\
\text { (TAMIR } \\
\text { EDLLEBiLiR) }\end{array}$ & $\begin{array}{l}\text { 11.4.1 Prematär/ } \\
\text { siddetli hassasiyet } \\
11.4 .2 \text { ciddi } \\
\text { gecikmigl' zayff }\end{array}$ & $\begin{array}{c}12.41 \\
\text { Kavitasyonlu } \\
\text { ẹtritik }\end{array}$ & 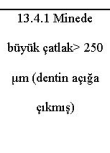 & $\begin{array}{c}14.4 .1 \text { Kabul } \\
\text { edilemeyen plak } \\
\text { birikimi }\end{array}$ & $\begin{array}{c}15.5 \text { Şuphcli } \\
\text { haff alerjik, } \\
\text { likenoid, toksik } \\
\text { reaksiyon }\end{array}$ & $\begin{array}{l}16.4 \text { Kalcc stmitl/' } \\
\text { genel stomatit, liken } \\
\text { planus, alerijik } \\
\text { reaksiyon: muidalalale } \\
\text { gerckli ancak }\end{array}$ \\
\hline & 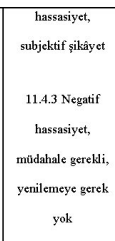 & $\begin{array}{c}\text { 12.4.2 dentinde } \\
\text { erozyon } \\
\text { 12.4.3 Dentinde } \\
\text { abrazyon' } \\
\text { abfraksiyon; struth } \\
\text { ve tamir edilebilir }\end{array}$ & 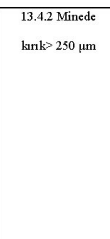 & $\begin{array}{c}\begin{array}{c}\text { 14.4.2 Kabul } \\
\text { edilemeyen dis eti } \\
\text { kanamas }\end{array} \\
\begin{array}{c}14.43 \text { Cep deriniligi? } \\
1 \mathrm{~mm}\end{array}\end{array}$ & & $\begin{array}{c}\text { yenilemeye gecrk } \\
\text { yok }\end{array}$ \\
\hline $\begin{array}{c}\text { 5. KTINIK } \\
\text { OLARAK } \\
\text { BASARISIZ } \\
\text { (YENILEME } \\
\text { GEREKLI) }\end{array}$ & $\begin{array}{l}11.5 \text { Şiddetli alut } \\
\text { pulpitisidevital } \\
\text { dis, endodontik } \\
\text { tedavi ve yeni } \\
\text { restorasyon } \\
\text { gercekli }\end{array}$ & $\begin{array}{c}12.5 \text { Derin, } \\
\text { dentine ulaşm § } \\
\text { ikincil ẹurriks } \\
\text { tammir edilemez }\end{array}$ & $\begin{array}{c}13.5 \text { Tưberkial ya } \\
\text { da diṣ lan̆ğ }\end{array}$ & $\begin{array}{l}14.5 \text { Ciddi gingivivitis } \\
\text { ya da periodontitis }\end{array}$ & $\begin{array}{l}15.5 \text { Șüpheli } \\
\text { eiddi alerjik, } \\
\text { likenoid, toksik } \\
\text { reaksiyon }\end{array}$ & $\begin{array}{l}16.5 \text { Ciddi Iokal' } \\
\text { genel semptom }\end{array}$ \\
\hline
\end{tabular}

Tüm bu bilgilerin ışığında yaptığımız çalışmanın amacı; monolitik zirkonya ve zirkonyum destekli seramik restorasyonların FDI kriterlerine göre klinik başarısını değerlendirmektir.

Bu amaçlara yönelik olarak çalışmamız 2 başlangıç hipotezini $(\mathrm{HO})$ test etmek amacıyla dizayn edilmiştir.

1. Monolitik zirkonya ve zirkonyum destekli seramik restorasyonların klinik başarıları arasında fark yoktur.

2. Bir yıl sonunda her iki restorasyon grubu için de $\% 100$ 'lük bir sağ kalım oranı bulunmuştur.

\section{GEREÇ VE YÖNTEM}

Çalışma protokolü, Marmara Üniversitesi Tıp Fakültesi Klinik Araştırmalar Etik Kurulu tarafından onaylandı (Ek 1). Katıımcı sayısı power analizi ile belirlendi. Eşleştirilmiş örneklem analizi kullanan gruplar arasındaki istatistiksel ola- rak anlamlı farkları, \% 95 güven ve \% 99,9 test gücü ile tespit etmek için her grupta en az 20 vaka gerekli bulundu. Marmara Üniversitesi Protetik Diş Tedavisi Anabilim Dalı'na başvurmuş olan çift taraflı alt çene 1. molar eksikliği olan 20 hastaya (14 kadın ve 6 erkek) toplamda 40 adet 3 üyeli köprü restorasyonu uygulandı (Resim 1).

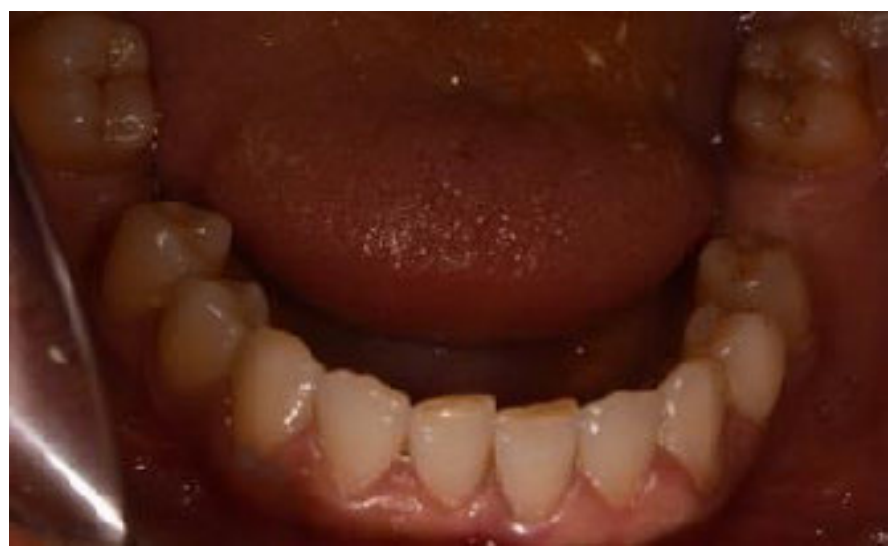

Resim 1. Tedavi öncesi

Bu randomize kontrollü, split-mouth klinik çalışmada, sadece hastaların uygulanan yöntemden ya da materyalden haberdar olmadığı tek kör tekniği kullanılarak hangi materyalin hangi tarafa uygulanacağı hastaya seçtirilen kapalı zarflar ile belirlendi. Bu sonuca göre belirlenen yarım çeneye 20 adet monolitik zirkonya köprü restorasyon (Zenostar T2, Wieland, Almanya) uygulanırken, diğer yarım çeneye ise 20 adet çift tabakalı yöntem ile zirkonyum destekli köprü restorasyon (IPS e.max ZirCAD MO 0, Ivoclar Vivadent, Schaan, Lihtenştayn) uygulandı. Bu çaıışmanın dahil edilme ve hariç tutulma kriterleri Tablo 4'de listelenmiştir.

Tablo 4. Dahil edilme ve hariç tutulma kriterleri.

\begin{tabular}{|c|c|}
\hline Dahil Edilme Kriterleri & Hariç Tutulma Kriterleri \\
\hline Sistemik hastallğga sahip olmamalidir. & \begin{tabular}{|l} 
Klinik semptomlu olan dişşler. \\
\end{tabular} \\
\hline $18-65$ yaş aralığnnda olmalıdrr. & Diş mobilitesi $\geq 2$. \\
\hline $\begin{array}{l}\text { Oral hijyen seviyesi yükssek bireyler (Plak indeksi ve gingival } \\
\text { indeksi değerleri } \leq 2 \text {.) }\end{array}$ & \begin{tabular}{|l} 
Implant ile tedavi endikasyonu. \\
\end{tabular} \\
\hline $\begin{array}{l}\text { Simetrik alt çene } 1 . \text { molar eksikliği nedeniyle üç ûyeli kōprü } \\
\text { restorasyon endikasyonu. }\end{array}$ & Dayanak dișinin gingivo-okluzal yüksekliği $33 \mathrm{~mm}$. \\
\hline Karş̧t arkta doğal diş bulunimalidir. & Dayanak dişserinde yetersiz klinik kron/kơk orant. \\
\hline $\begin{array}{l}\text { Dayanak dișlerin aktif bir periodontal ya da pulpal hastallĭğ } \\
\text { olmamald dr. }\end{array}$ & \begin{tabular}{|l|} 
Parafonksiyonel alışkanlıklar. \\
\end{tabular} \\
\hline
\end{tabular}

Çalışmaya başlamadan önce tüm katıımcılar çalışmanın amaçları, yöntemleri, faydaları ve riskleri ile ilgili bilgilendirildi ve onam formlarına yaziı onay verdi.

Dişlerin preparasyonu sırasında taramaların intraoral tarayıCı (CEREC AC Omnicam, Sirona, Bensheim, Almanya) ile yapılacağı göz önüne alınarak lokal anestezi altında okluzal yüzden 1,5- $2 \mathrm{~mm}$; aksiyel yüzden $3^{\circ}$ lik aksiyal eğime sahip olacak şekilde 1,5 mm'lik indirgeme uygulandı (Resim 2). 


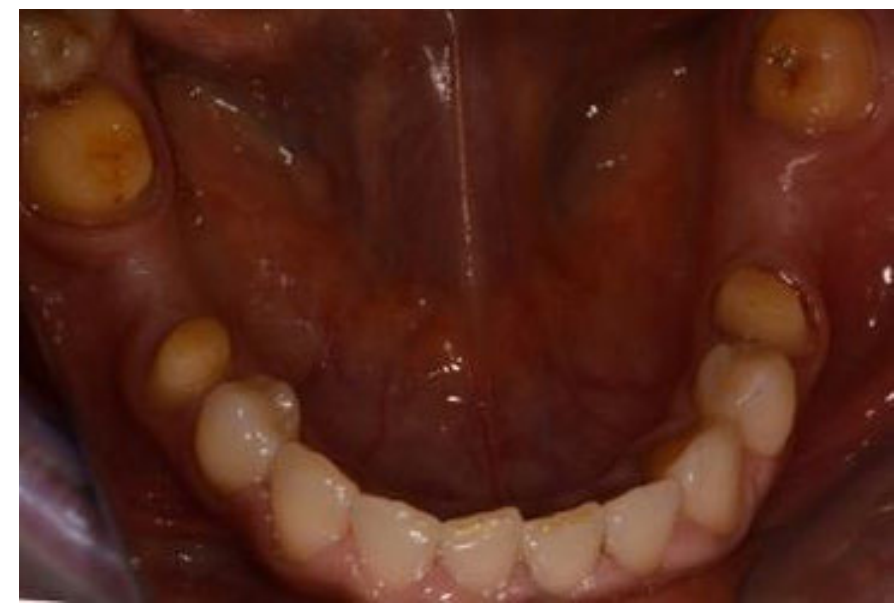

Resim 2. Preparasyon

Preparasyonun bitim sınırı chamfer frez (Acurata, $\mathrm{G}+\mathrm{K}$ Mahnhardt Dental e.K, Thurmansbang, Almanya) kullanılarak dişeti seviyesinde hazırlandı. Retraksiyon (Ultrapak E Cord, Ultradent Dental Products, South Jordan, UT, ABD) işlemini takiben intraoral tarayıcı (CEREC AC Omnicam, Sirona, Bensheim, Almanya) ile preparasyon yapılan ve karşıı̆ındaki dental arkın tümü tarandı. İnterokluzal kapanış kaydı, hastaların sentrik ilişkileri konumunda kaydedildi.

Tarama sonrsı elde edilen tüm dijital model verileri, restorasyonların tasarlanması için STL dosyası olarak laboratuar tipi CAD yazılımına (inLab 16.2 SW CAD, Sirona, Bensheim, Almanya) aktarıldı. Zirkonyum destekli restorasyonların altyapıları $(n=20)$ ve tam kontur monolitik zirkonya restorasyonları $(n=20)$, inLab 16.2 SW CAD yazılımnda tasarlandı ve beş eksenli bir freze makinesi (inLab, MC X5, Sirona, Bensheim, Almanya) kullanılarak üretildi. Zirkonyum destekli restorasyonlar için Yyttrium stabilize edilmiş zirkonyum dioksit diskler (IPS e.max ZirCAD MO 0, Ivoclar Vivadent, Schaan, Lihtenştayn), monolitik zirkonya restorasyonları için translusent monolitik zirkonya diskler (Zenostar T2, Wieland, Almanya) kullanıldı. Üretimden sonra zirkonya restorasyonlar seramik bir firında sinterlendi (Lava Furnace 200, 3M ESPE, St. Paul, MN, ABD), sinterizasyon sonrası yaklaşık \%20'lik bir büzülmeye uğrayarak daha yoğun ve dayanıklı hale ulaşıldı. Zirkonyum destekli restorasyonlar için ilk olarak altyapı üzerine, üstyapıyla bağlantıyı artıran bir malzeme olan ara katman (IPS e. max Ceram ZirLiner, ZirLiner Build-Up Liquid, Ivoclar Vivadent, Schaan, Lihtenştayn) uygulanmıştır. Daha sonra nano-fluroapatit cam-seramik (IPS e-max Ceram, Ivoclar Vivadent, Schaan, Lihtenştayn) ile tabakalama tekniği kullanılarak veneerlendi ve bir seramik fırınında (Programat P310, Ivoclar Vivadent, Schaan, Lihtenştayn) sinterlendi. Tüm restorasyonların proksimal ve okluzal temasları kontrol edilerek ağız içi provası tamamlandı. Bu işlemi takiben restorasyonlar, üreticinin talimatlarına uygun olarak glazelendi glazür (IPS e.max Ceram Glaze powder, IPS Ivocolor Mixing Liquid Allround, Ivoclar Vivadent, Schaan, Lihtenştayn).

Restorasyonların iç yüzeyi 0,25 MPa'lık basınç altında 50 $\mu m^{\prime}$ luk Al2O3 partikülleriyle ile kumlandı ve basınçlı su ile yıkanıp kurutuldu. Sonrasında self adeziv rezin siman (SpeedCEM Plus, Ivoclar Vivadent, Schaan, Lihtenştayn) otomatik şırıngası yardımıyla restorasyonun içine istenen miktarda doğrudan uygulandı. Restorasyon çepeçevre 2'şer saniye polimerize edildikten sonra sond yardımıyla diş yüzeyindeki; diş ipi yardımıyla da (Oral B Essential Floss, P\&G, ABD) ara yüzlerdeki siman fazlalıkları uzaklaştırıldı. Restorasyonun tüm marjin bölgeleri, 20 sn süreyle Işık cihazı (Bluephase LED, Ivoclar Vivadent, Schaan, Lihtenştayn) uygulamasına tabii tutularak polimerizasyon işlemi tamamlandı (Resim 3).

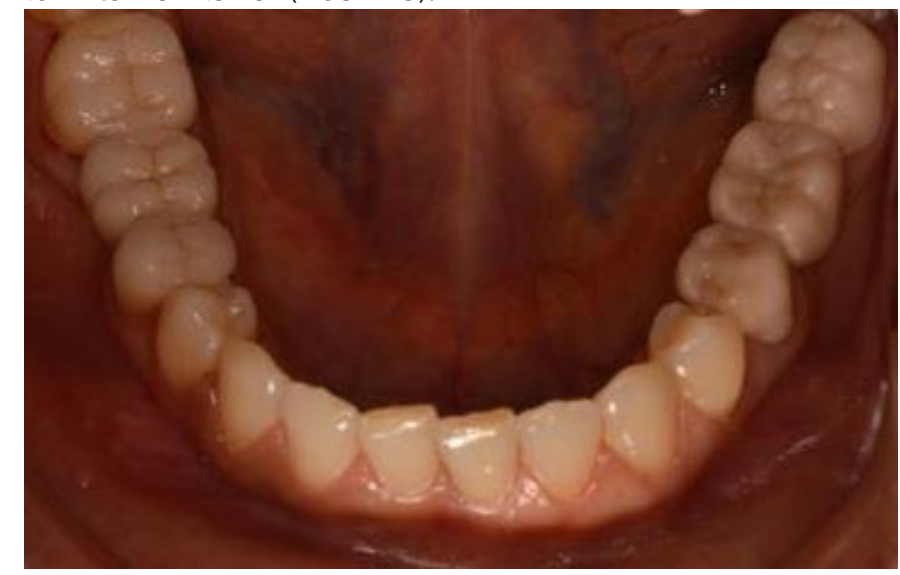

Resim 3. Tedavi sonrası

Restorasyonlar simante edildikten sonra 1. hafta, 6 . ay ve 1. yılda klinik olarak değerlendirildi. Klinik incelemeler, FDI (World Dental Federation)'ın onayladığı kriterler kullanılarak iki farklı gözlemci tarafından 5 farklı skorda uzlaşma metodu ile yapıldı. Toplamda bu skorlardan; 1 (bir) klinik olarak mükemmel tüm standartları taşıyan restorasyonları, 2 (iki) klinik olarak iyi ancak tamamen ideal olmayan restorasyonları, 3 (üç) klinik olarak yeterli ancak bazı kabul edilebilir eksiklikleri bulunan restorasyonları, 4 (dört) klinik olarak kabul edilemeyecek ancak tamir edilebilir restorasyonları ve 5 (beş) klinik olarak başarısız ve derhal değiştirilmesi gereken restorasyonları ifade etmektedir. Farklı skorlar elde edildiğinde, tekrar değerlendirme yapılarak fikir birliği sağlandı. Kullanılan FDI kriterleri estetik, fonksiyonel ve biyolojik olmak üzere üç farklı kategoride değerlendirildi.

Çalışmamızda elde edilen veriler IBM SPSS (Statistical Package for Social Sciences) for Windows V23 (SPSS Inc, Chicago, ABD) ile analiz edildi. Normal dağılmayan verilerin grup içi karşılaştırılmasında 3 farklı zaman değerlendirildiği için Friedman testi kullanıldı. Anlamlı fark çıktığında hangi zamanlar arasında fark olduğuna karar vermek için ikili zaman karşılaştırmaları Wilcoxon testi ile yapıldı. Önem düzeyi $p<0,05$ olarak alındı.

\section{BULGULAR}

Restorasyonların FDI kriterlerine göre başlangıç, 6. ay ve 1. yıl klinik değerlendirmeleri sonucu elde edilen skorlar Tablo 5 ve 6'da; bu sonuçların yüzdelik değerlendirmeleri ise Tablo 7'de gösterilmiştir. Kabul edilebilir skorların yüz- 
delerinin zaman içerisindeki değişim değerlendirmeleri ise Tablo 8'de gösterilmiştir.

Elde edilen verilere göre çift tabakalı ve monolitik restorasyonlarda estetik kriterlerden "yüzey parlaklığı", "yüzeyel ve marjinal renklenme", "renk uyumu ve translusensi", "estetik ve anatomik form" değerlerinde zaman içerisinde istatistiksel olarak anlamlı bir fark gözlenmemiştir ( $p>0,05)$. Çift tabakalı ve monolitik restorasyonların 1. yıl kontrolünde kırılma, debonding veya gözle görülür chippinge rastlanmamıştır. Fonksiyonel kriterlerden "retansiyon ve materyal kırığı", "marjinal adaptasyon", "okluzal kontur ve yıpranma", "aproksimal anatomik form", "radyografik değerlendirme" ve "hasta memnuniyeti" değerleri de zamanla farklılık göstermedi ( $p>0,05)$. Ancak hasta memnuniyeti skorları zirkonyum destekli restorasyonlar için tüm kontrol seanslarının \%85'inde 1 (estetik ve fonksiyonel olarak tam kabul edilebilir), \%15' inde 2 (yeterli estetik ve fonksiyon) olarak; monolitik zirkonya restorasyonlar için başlangıç ve 6 . aylarda \%5'inde 2 (yeterli estetik ve fonksiyon) olup, 1. yılda tüm skorlar 1 (estetik ve fonksiyonel olarak tam kabul edilebilir) olarak elde edilmiştir.

Biyolojik kriterlerden "Postoperatif hassasiyet ve diş vitalitesi" çift tabakalı restorasyonlar için başlangıç değerlendirmelerinde \%25 oranında 2 (sınırlı bir süre için az hassasiyet, normal vitalite) skoru gözlenirken 6.ayda \%20 ve zamanla tüm skorlar 1 (hassasiyet yok, normal vitalite) olacak şekilde; monolitik restorasyonlar için ise başlangıç değerlendirmelerinde \%30 oranında 2 (sınırlı bir süre için az hassasiyet, normal vitalite), 6. ayda \%10 oranında 2 skoru gözlenirken 1.yılda 1 (hassasiyet yok, normal vitalite) olacak şekilde değişmiştir. "Periodontal cevap", "çürük tekrarı/erozyon/abfraksiyon", "diş bütünlüğü" ve "komşu mukoza" ve "oral ve genel sağlık durumu" değerleri her iki restorasyon tipi içinde istatistiksel olarak anlamlı farklılık göstermemiştir ( $p>0,05)$.

Çalışmamızdaki gruplar arası estetik kriterler incelemelerinde "yüzey parlaklığı", "yüzeyel ve marjinal renklenme değerlendirmesi" skorları çift tabakalı ve monolitik restorasyonlar için istatistiksel olarak anlamlı bulunmamıştır (p>0,05). "Renk uyumu ve translusensi" skorları başlangıç değerleri restorasyon tipine göre farklılık göstermektedir ve monolitik restorasyonlarda değerler daha yüksektir $(p=0,005)$. Fonksiyonel kriterler ve biyolojik kriterler incelemelerinde her bir zaman diliminde restorasyon tipine göre istatistiksel olarak anlamlı farklılık gözlenmemiştir ( $p>0,05)$.

\section{TARTIŞMA}

Ağız içi simetrik (split mouth) olarak tasarladığımız bu in-vivo çalışmada monolitik zirkonya ve zirkonyum destekli seramik 3 üye köprü restorasyonların klinik başarısı, hasta memnuniyeti, marjinal/internal adaptasyonları ve restorasyonların aşınması ile karşıt dentisyonda oluşan aşınma karşılaştırılmıştır. Literatür taramaları sonucunda aynı şekilde tasarlanmış başka bir çalışma bulunamadığından dolayı tartışmada benzer çalışmalara yer verilmiştir. Çalışmamızdan elde edilen bulguların ışığında "Monolitik zirkonya ve zirkonyum destekli seramik restorasyonların klinik başarıları arasında fark yoktur." hipotezi reddedilmiştir. FDI değerlendirmesinde, estetik kriterlerden 'renk uyumu ve translusensisi' ile 'estetik ve anatomik form' skorları arasında istatistiksel olarak anlamlı fark bulunmuştur. Periodontal klinik parametrelerin değerlendirilmesinde ise monolitik zirkonya ve zirkonyum destekli seramik restorasyonlar arasında fark bulunmamıştır. "Bir yıl sonunda her iki restorasyon grubu için de \%100'lük bir sağ kalım oranı bulunmuştur." hipotezi kabul edilmiştir.

Dijital diş hekimliğinde yaşanan gelişmelerin yansıması olan CAD/CAM sistemindeki tarama cihazlarının gelişmiş netliği, yazılım programlarının artmış kapasiteleri, frezeleme ünitelerinin hassasiyetinin gelişimi ile, metalsiz materyaller ve restorasyon üretim teknikleri hastalara sunulmaktadır. Teknolojide yaşanan bu gelişmeler laboratuvarda harcanan zamanı azaltmakta ve hastalara daha uyumlu ve estetik restorasyonlar daha kısa sürede uygulanabilmektedir. ${ }^{14}$ CAD/CAM sistemi ile üretilen restorasyonların geleneksel teknik ile üretilenlerden daha iyi adaptasyona sahip olduğu belirtilmektedir.7,15 Bu nedenle, bu çalışmada, tüm preperasyonların ölçüsü intraoral tarayıcı ile dijital olarak alınmıştır. Monolitik zirkonya restorasyonlar ve zirkonyum destekli restorasyonların altyapısı CAD / CAM teknolojisi ile inLab MC X5 kullanılarak, üstyapısı ise konvansiyonel tabakalama tekniği ile üretilmiştir.

Posterior diş eksikliklerinin tedavisinde sabit bölümlü protezler uzun süreli çalışmalarla desteklenen, sıklıkla tercih edilen ve başarısızlık oranlarının çok düşük olduğu tedavi seçeneğidir. ${ }^{3,16}$ Sabit bölümlü protezlerin posterior bölgedeki diş eksikliklerinde kullanımı için yüksek mekanik özellik gösteren materyallerden elde edilmiş restorasyonlar önerilmektedir. Metal destekli seramik restorasyonlar diş hekimliğinde 50 yılı aşkın süredir klinik olarak başarıyla kullanılmaktadır. ${ }^{3}$ Ancak metal altyapının ve metal altyapı üzerinde yer alan opak seramiğinin ışık geçirgenliğini engellemesi, dişeti kenarından metal-iyon renklenmesine yol açması sonucu diş eti boyunca 'siyah çizgi' denilen metal yansıması ortaya çıkabilmesi ve yumuşak ve sert dokularda alerjik ya da korozyon toksisitesine neden olma potansiyeline sahip olması gibi dezavantajları yüzünden yerine yeni arayışların doğmasını gerektirmiştir. Günümüzde artan estetik beklenti diş renginde olan restorasyonlara ilgiyi artırmıştır ve estetik açıdan tolere edilebilen metal desteksiz tam seramik restorasyonların kullanımı gündeme gelmiştir. ${ }^{3}$ Tam seramik restorasyonların, doğal diş dokusuna benzer ısısal genleşme katsayısına, ısı iletkenliğine sahip olmaları ve ışığı geçirme, yansıtma özellikleri sebebiyle günümüzde estetik tercih sebebidir. Ancak özellikle posterior bölgede 3 üyeyi aşan restorasyonlarda 
okluzal kuvvetlere karşı yetersiz kırılma dayanımından dolayı güçlendirilmiş tam seramik sistemleri geliştirilmiştir. Zirkonya destekli restorasyonlar, biyouyumlu olmaları, düşük bakteri adezyonu göstermeleri, konvansiyonel ve rezin simanlar ile simante edilebilmeleri, düşük termal iletkenlik, asit ve alkali içinde korozyona direnç, çeliğe benzer elastiklik modülü gibi özellikleri sayesinde 1990'lı yıllardan itibaren diş hekimliğinde yaygın bir şekilde kullanılmaktadır ve posterior köprü restorasyonlarında altın standart olarak kabul edilen metal seramik restorasyonlara alternatif oluşturmaktadır. ${ }^{2}$ Yukarıdaki tüm parametreler göz önünde bulundurularak çalışmamızda zirkonya restorasyonların 1 yııık klinik takibi ile başarısı değerlendirilmiştir.

Yttrium ile stabilize edilmiş (\%2-3 mol) zirkonyum (Y-TZP) materyali, protetik restorasyonlarda öncelikle altyapı materyali olarak kullanılmaya başlanmış ve üstyapı seramiği ile veneerlenerek kullanılmıştır. Üstyapı seramiğinin altyapıdan tabaka halinde (delaminasyon) ya da kırılarak ayrılması (chipping) sonucu görülen başarısızlık oranının ve klinik takibinde sekonder çürük görülme sıklığının metal destekli restorasyonlardan daha yüksek bulunduğudu unutulmamalıdır. ${ }^{5} \mathrm{Bu}$ başarısızlığa zirkonya altyapı ile üstyapı seramiği arasında oksit tabakası oluşmamasının ve termal genleşme katsayılarının uyumsuzluğunun sebep olduğu düşünülmektedir. ${ }^{4}$ Zirkonya restorasyonlarda karşılaşılabilen üstyapı sorunları, dijital veneerleme yöntemi ile ya da zirkonyum oksit içeren restoratif materyaller ve (CAD / CAM) sistemlerinin geliştirilmesi ile üstyapı seramiği kullanımayan monolitik (tam konturlu) zirkonya restorasyonların üretimiyle giderilmeye çalışılmaktadır.7 Monolitik zirkonya materyali yüksek bükülme dayanımı, diş rengine yakın rengi, antagonist dişte az aşındırma meydana getirmesi, konservatif diş preparasyonuna izin vermesi ve daha az üretim zamanı ve maliyeti gerektirmesi gibi özellikleri sayesinde çift tabakalı restorasyonlar karşısında kullanımı artmaya başlamıştır. ${ }^{6}$ Bu nedenle çalışmamızda iki farklı üretim yöntemiyle hazırlanan zirkonya restorasyonların (çift tabakalı ve monolitik) birbirine olan üstünlüğü split-mouth olarak karşılaştırıldı. Çift tabakalı restorasyonların üretimi veneer seramiği ile altyapı üzerine tabakalama yöntemi kullanılarak gerçekleştirildi.

Çalışmalara bakıldığında yaşam ömrü değerlendirmelerinde farklı başarı kriterlerinin kullanıldığı görülmektedir. Bazı literatürlerde başarısızlık sadece kırık restorasyonları ifade ederken, ${ }^{17}$ bazı çalışmalarda herhangi bir nedenden ötürü yenilenen restorasyonları ${ }^{18}$ bazılarında ise yenilenen veya tamir görerek ağızda kalan tüm restorasyonlar başarısız olarak nitelendirilmiştir. ${ }^{19}$ Araştırmacıların farklı başarı kriterlerine göre birden fazla yaşam ömrünü hesapladığı çalışmalar da bulunmaktadır. ${ }^{20}$ Beuer ve arkadaşlarl,21 kısmi sinterize zirkonya (IPS e.max ZirCAD; IvoclarVivadent) altyapılar, konvansiyonel üstyapı seramiği (IPS e.max Ceram; IvoclarVivadent) kullanılarak elde edilen 18 sabit bölümlü protez, 50 tek üye restorasyonun 3 yıl klinik takibini yapmışlardır, restorasyonların \%88,2'sinde herhangi bir komplikasyon gözlenmemiştir. Başarısızıkların $\% 7,4^{\prime}$ ü üst yapı kırıklarını da içeren teknik komplikasyonlar olarak belirtilmiştir. ${ }^{21}$ Pelaez ve arkadaşları, ${ }^{22} 3$ üyeli Lava restorasyonların 4 yıllık klinik takiplerini yaptıkları çalışmalarında, 20 restorasyonun hiçbirinde altyapı kırığı gözlenmediği, 2'sinde üstyapı kırığı gözlendiğini belirtmişlerdir. Rinke ve arkadaşları, ${ }^{23}$ 3-4 üyeli Cercon restorasyonların 7 yıllık klinik takibini yaptıkları çalışmalarında, 97 restorasyonun beşinde alt yapı kırığı, 23 'ünde ise üstyapı kırığı gözlemlemişlerdir. Sulaiman ve arkadaşları24 2016 yılında yaptıkları çalışmada 5 yıllık klinik takip ile monolitik zirkonya restorasyonların başarısızlıklarını değerlendirmişlerdir. Toplam 39827 monolitik zirkonya restorasyon kaydı incelenmiş olup bunların 3731 tanesi anterior bölgede (1952 tek kron; 1799 köprü restorasyon); 36096 tanesi posterior bölgede (29808 tek kron; 6288 köprü restorasyon) bulunmaktadır. Beşinci yııın sonunda kırık oranları tüm anterior restorasyonlarda \%2,06; tüm posterior restorasyonlarda \%0,99 bulunmuştur. Köprü restorasyonlarında, tek krona oranla 2 kat fazla başarısızlık gözlenmiştir. ${ }^{24}$ Bömicke ve arkadaşları25 yapmış oldukları in vivo çalışmada 90 monolitik, 72 çift tabakalı zirkonya tek kronu sağ kalım oranlarına göre değerlendirmişlerdir. Üç yıllık klinik takip sonunda sağ kalım, monolitik zirkonya restorasyonlar için \%100; çift tabakalı zirkonya restorasyonlar için $\% 98,5$ bulunmuştur. ${ }^{25}$ Bankoğlu Güngör ve arkadaşlarının ${ }^{26}$ tek kron ve köprü monolitik zirkonya restorasyonlarda yapmış oldukları ortalama 18 aylık klinik takip çalışmasında başarı oranları sırasıyla \%86,7 ve \%92,3 olarak bulunmuştur. Konstantinidis ve arkadaşları27 65 monolitik zirkonya kronun 1 yıllık klinik takibini yaptıkları çalışmalarında \%100'lük bir sağ kalım oranı elde etmişlerdir. Çalışmamızda 1 yıllık takipleri yapılan zirkonyum destekli ve monolitik zirkonya restorasyonların yaşam ömrü değerlendirmelerinde herhangi bir üstyapı veya altyapı kııı̆ı vakasıyla karşılaşıımamıştır. Her iki restorasyon grubu için 1 yıl sonunda \%100'lük bir yaşam ömrü söz konusudur. Çalışmamızda elde edilen yüksek sağ kalım oranları diğer çalışmaların sonuçlarından da desteklenmektedir. ${ }^{27-29}$

Marquillier ve arkadaşlarının ${ }^{30}$ klinik değerlendirmeler hakkında yayınladıkları çalışmasında 2007 yıında yayınlanan FDI kriterlerinin 2017 yılına kadar geçen 10 yıllık süreçte indirekt ve direkt restorasyonların değerlendirilmesinde kullanım oranları araştırımıştır. 2016 yılında yayınlanan çalışmaların \%50'sinde 2017 yılında ise yayınlanan çalışmaların $\% 87,5^{\prime}$ inde bu kriterlere göre değerlendirme yapıldığı görülmüştür. Ancak son 10 yıl ortalaması alındığında FDI kriterlerinin klinik çalışmalarda kullanım oranın \%16.3 olduğu görülmüştür. ${ }^{30}$ Çalışmamızda FDI kriterlerinin giderek artan kullanımı ve modifiye USPHS 
kriterlerine kıyasla daha detaylı klinik inceleme yapılmasına imkân vermesi sebebi ile kullanılmıştır. Literatürde FDI kriterlerinin çalışmamıza benzer şekilde dizayn edilmiş herhangi bir klinik takip çalışmasında kullanılmadığı görülmüştür. Dolayısı ile kıyaslamalar modifiye USPHS kriterleri kullanılarak yapılmış çalışmalar ile yapılmıştır. Bizim çalışmamızda herhangi bir grubun lehine veya aleyhine oluşabilecek önyargılı değerlendirmeleri önlemek için takip seanslarındaki değerlendirmeler skorda uzlaşma metodu ile biri uygulayan hekim olacak şekilde 2 farklı klinisyen tarafından yapılmıştır. Çalışmamızda FDI değerlendirme kriterlerine göre yapılan başlangıç, 6. ay ve 1. yıl kontrol değerlendirmelerinde zirkonyum destekli ve monolitik zirkonya restorasyonlar klinik olarak kabul edilebilir bulunmuştur.

Raigrodski ve arkadaşları ${ }^{31} 16$ hastaya, 20 üç üyeli posterior zirkonyum (Lava) destekli restorasyonlar uygulamışlardır. Üç yıllık klinik takip sonucu USPHS kriterleri kullanılarak değerlendirilmiştir. 15 restorasyon tüm kriterler için Alfa olarak derecelendirildi. Dört restorasyonda chipping gözlenmesi nedeniyle, 1 restorasyonda ise marjinal adaptasyon açısından bravo olarak değerlendirildi. Pihlaja32 2016'da zirkonya tek kron ve köprü restorasyon uygulanan 76 katılımcının genel memnuniyeti yüksek bildirilmiştir: \%96'sı estetik ve anatomik form, \%99'u renk uyumu ve translusensi, \%100'ü yüzey parlaklığı ile tatmin olarak tespit edilmiştir. Anatomik konturu \%97; marjinal adaptasyon \%100; marjinal renklenme \%98,4; okluzal kontur ve yıpranma hafif pürüzlü bir yüzey oluşması nedeniyle \%44 oranında çok iyi olarak değerlendirildi. En sık görülen komplikasyonları desimantasyon (\%5) ve kırık (\%4) olarak bildirmiştir; sekonder çürük ve endodontik tedavi ihtiyacı gözlenmemiştir. Ankete katılanlar tarafından tanımlanan olağan semptomlar, donuk ağrı (9 hasta, \%12), soğuğa aşırı duyarlılık (8 hasta, \%11) ve diş eti kanaması (4 hasta, \%11) olarak bildirilmiştir. ${ }^{32}$ Son zamanlarda yapılan meta-analizlerde, zirkonya tek kronlarda köprü restorasyonlara göre belirgin şekilde daha yüksek oranda sekonder çürük bildirilmiştir. ${ }^{33,34}$ Sekonder çürüğün gözlenmediği çalışmalarda mevcuttur. ${ }^{4,35}$ Tartaglia ve arkadaşları ${ }^{36}$ yaptıkları 7 yıllık klinik takibin sonunda sekonder çürük nedeniyle $\% 0,7$ başarısızlık bildirmişlerdir. Konstandinis ve arkadaşları $^{27} 2018$ yılında yapmış oldukları prospektif, 1 yıllık klinik takip çalışmasında sekonder çürük gözlemediklerini ve bu durumu da monolitik zirkonya kronların başarılı marjinal adaptasyonu sayesinde olduğunu bildirmişlerdir. Çalışmamızda her iki restorasyon tipi içinde "yüzey parlaklığı" ve "yüzeyel ve marjinal renklenme" değerlendirmesi \%100 başarılı bulunmuştur ve 1. yıl sonunda elde edilen klinik skorların tüm gruplarda kabul edilebilir olduğu görülmüştür. "Renk uyumu ve translusensi" ile "estetik ve anatomik form" gruplar içinde zamana bağlı değişim göstermemekle birlikte gruplar arası sırayla zirkonyum des- tekli restorasyon için diğeri ise monolitik zirkonya restorasyon için başarılı bulunmuştur. "Çürük tekrarı/erozyon/ abfraksiyon" değerlendirmesi için ise 1 yıllık klinik takip sonucunda mevcut dişlerin hiçbirisinde sekonder çürüğe rastlanmamış olup restorasyon yenilenmesi veya endodontik tedavi ihtiyacı duyulmamıştır.

Bankoğlu Güngör ve arkadaşlarının ${ }^{26}$ tek kron ve köprü monolitik zirkonya restorasyonlarda yapmış oldukları ortalama 18 aylık klinik takip çalışmasında restorasyonlarda iyi marjinal adaptasyon ve anatomik kontur gösterdiği; ancak restorasyonların renk ve oklüzyon için düzenlemelere gerek duyduğu belirlendi. Konstandinis ve arkadaşlarının ${ }^{27}$ yapmış oldukları in vivo çalışmada 1. yılın sonunda yüzey pürüzlülüğü için Bravo ile derecelendirilen restorasyonlar \%4,7 oranında artmıştır. Bu durumu, yüzey pürüzlülüğünü etkileyen diş fırçalama, aşınma veya yıpranma gibi faktörlere bağlamıştır. ${ }^{37}$ Tang ve arkadaşları ${ }^{38}$ yaptıkları in vivo çalışmada posterior dişlere uygulanan 46 monolitik zirkonya tek kronların 96 hafta klinik takibini yapmışlardır ve CDA kriterleri ile değerlendirmişlerdir. Uygulanan tüm restorasyonların marjinal adaptasyonları \%100 oranında başarılı bulunmuştur. Marjinal renklenme, ikincil çürük ve restorasyon kırıkları gözlenmemiştir. Renk uyumu için 3 (\%6,1); anatomik form için 2 vaka $(\% 4,1)$ kabul edilebilir olarak diğerleri ise mükemmel bulunmuştur. Yüzey pürüzlülüğü ile ilgili olarak, kabul edilebilir derecelendirme 2. Hafta kontrolünde \%4,1'den \%6,1'e yükselmiştir. İkinci yıl kontrolünden 3. yıl kontrolüne kadar kabul edilebilir oran \%2,0’ye düşerken, sadece 1 vaka kabul edilebilir olarak değerlendirilmiştir. ${ }^{38}$ Çalışmamızda elde edilen sonuçların Bankoğlu Güngör ve arkadaşlarının ${ }^{26}$ yaptıkları çalışma sonuçları ile paralel olduğu gözlenmektedir. Restorasyonların tümünde iyi "marjinal adaptasyon" ve "aproksimal anatomik form" gözlenmiştir.

Pjetursson ve ark. ${ }^{33}$ ve Sailer ve ark. ${ }^{34}$ zirkonya tek kronların ve köprü restorasyonlarının, metal seramik restorasyonlardan çok daha fazla retansiyon kaybına uğradığını ve desimante olduğunu bildirmiştir. Tartaglia ve arkadaşları, ${ }^{36} 7$ yıllık klinik takip sonucu zirkonya tek kronlar için \%2,3; köprü restorasyonlar için \%0 retansiyon kaybı bildirmiştir ve Monaco ve arkadaşları4 zirkonya restorasyonlar için 5. yıl sonunda sadece \%0,2 retansiyon kaybı tanımlamışlardır. Çalışmamızda FDI'in fonksiyonel kriterlerinin kırık/chipping/debonding" değerlendirmesinde, 1. yıl sonunda tüm gruplarda hiç kırık veya debonding görülmemiştir, retansiyon kaybı yaşanmamıştır. Başlangıç, 6. ay ve 1. yıl skorları arasında bir değişim görülmemiştir.

Zirkonya restorasyonların uzun dönem klinik takip çalışmalarında, postoperatif hasssasiyet genellikle izlenmemektedir. ${ }^{27} \mathrm{Bu}$ durum üzerinde, zirkonya restorasyonlarda kullanımı önerilen rezin simanların sızdırmazlığı, diş preparasyonu ve restorasyonların marjinal uyumlarının etkili olduğu düşünülmektedir. ${ }^{38}$ İmmediat hassasiyet, diş pre- 
parasyonundan hemen sonra oluşan hassasiyet, ikincil hasasasiyet ise mikrosızıntıya bağlı oluşabilecek hassasiyet biçimidir. ${ }^{35}$ Çalışmamızda postoperatif hassasiyet başlangıç, 6 . ay ve 1. yıl kontrollerine göre karşılaştırıımasında zaman bağlı karşılaştırmasında istatistiksel olarak anlamlı azalmıştır. Postoperatif hassasiyet klinik olarak kabul edilebilir düzeyin üstünde izlenmemiştir.

\section{SONUÇ}

Bu çalışmada elde edilen veriler doğrultusunda şu sonuçlar elde edilmiştir:

1. Çalışmamızda, zirkonya restorasyonların 1 yıllık klinik takibinde klinik olarak kabul edilebilir olduğu bulunmuştur. Başlangıç, 6 ay ve 1 yıllık takip periyotlarında monolitik ve çift tabakalı zirkonya restorasyonların klinik başarıları arasında anlamlı fark olmadığı gözlenmiştir.

2. FDI kriterleri kullanılarak yapılan incelemelerde "renk uyumu ve translusensi" değerlendirmelerinde zirkonyum destekli restorasyonların; "estetik ve anatomik form" değerlendirmelerinde monolitik zirkonya restorasyonların daha başarılı sonuçlar verdiği görülmüştür. Diğer klinik değerlendirme skorlarında anlamlı farkların olmadığı tespit edilmiştir.

3. Her iki restorasyon tipinde de simantasyonu takiben postoperatif hassasiyetlerin oluşabildiği bildirilmiştir. Ancak 6. aya kadar bu hassasiyetin ortadan kalktığı ve çalışmadaki tüm vital dişlerin 1. yıl sonunda vitalitesini koruduğu görülmüştür.

4. Her grubun 1. yıl sonundaki sağ kalım oranları \%100 olarak belirlenmiştir. Monolitik zirkonya restorasyonların sağ kalım oranlarında zirkonyum destekli restorasyonlar kadar başarılı sonuçlar verdiği görülmüştür. Estetik, fonksiyonel ve biyolojik kriter skorları klinik olarak kabul edilebilir seviyede gözlenmiș ve 1.yıl sonunda restorasyonlarda yenileme gereksinimi olmamıştır.

Teşekkür

Bu çalışma, Marmara Üniversitesi Bilimsel Araştırma Projeleri Komisyonu Başkanlığı tarafından SAG-CDRP-131217-0664 numaralı proje ile desteklenmiştir.

\section{KAYNAKLAR}

1. Vagkopoulou T, Koutayas SO, Koidis P, Strub JR. Zirconia in dentistry: Part 1. Discovering the nature of an upcoming bioceramic. Eur J Esthet Dent 2009; 4:130- 151.

2. Zhang Y. Making yttria-stabilized tetragonal zirconia translucent. Dent Mater 2014; 30: 1195-203.

3. Sailer I, Balmer M, Hüsler J, Hämmerle CHF, Känel S, et al. 10-year randomized trial (RCT) of zirconia-ceramic and metal-ceramic fixed dental prostheses. J Dent 2018; 76: 32-39.

4. Monaco C, Caldari M, Scotti R. Clinical evaluation of zirconia-based single crowns: a retrospective cohort study from the AIOP clinical research group. Int $\mathrm{J}$ Prosthodont 2013; 26:435-442.

5. Rinke S, Wehle J, Schulz X, Bürgers R, Rödiger M.
Prospective Evaluation of Posterior Fixed Zirconia Dental Prostheses: 10-Year Clinical Results. Int J Prosthodont 2018; 31: 35-42.

6. Bankoğlu Güngör M, Karakoca Nemli S. Fracture resistance of CAD-CAM monolithic zirconia molar crowns after aging in a mastication simulator. J Prosthet Dent 2018; 119: 473-480.

7. Kale E, Seker E, Yilmaz B, Ozcelik TB. Effect of cement space on the marginal fit of CAD-CAM-fabricated monolithic zirconia crowns. J Prosthet Dent. 2016; 116: 890-895.

8. Sun T, Zhou S, Lai R, Liu R, Ma S, Zhou Z, Longquan S. Load-bearing capacity and the recommended thickness of dental monolithic zirconia single crowns. J Mech Behav Biomed Mater 2014; 35: 93-101.

9. Janyavula S, Lawson N, Cakir D, Beck P, Ramp LC, Burgess JO. The wear of polished and glazed zirconia against enamel. J Prosthet Dent 2013; 109: 22-29.

10. Randall RC, Wilson NHF. Clinical testing of restorative materials some historical landmarks. J Dent 1999; 27: 543-50.

11. Sailer I, Bonani T, Brodbeck U, Hammerle $\mathrm{CH}$. Retrospective clinical study of singleretainer cantilever anterior and posterior glass-ceramic resin-bonded fixed dental prostheses at a mean follow-up of 6 years. Int $\mathrm{J}$ Prosthodont 2013; 26: 443-50.

12. Beier US, Kapferer I, Burtscher D, Dumfahrt H. Clinical performance of porcelain laminate veneers for up to 20 years. Int J Prosthodont 2012; 25:79-85.

13. Hickel R, Peschke A, Tyas M, Mjor I. FDI World Dental Federation: clinical criteria for the evaluation of direct and indirect restorations-update and clinical examples. Clin Oral Invest 2010; 14: 349-366.

14. Lee $B$, Oh KC, Haam D, Lee JH, Moon HS. Evaluation of the fit of zirconia copings fabricated by direct and indirect digital scanning procedures. J Prosthet Dent 2018; 120: 225-31.

15. Ueda K, Beuer F, Stimmelmayr M, Erdelt K, Keul C, et al. Fit of 4-unit FDPs from $\mathrm{CoCr}$ and zirconia after conventional and digital impressions. Clin Oral Invest 2016; 20: 283-289.

16. Tonetti MS, BottenbergP, Conrads G, Eickholz P, Heasman $P$, et al. Dental caries and periodontal diseases in the ageing population: call to action to protect and enhance oral health and well-being as an essential component of healthy ageing-consensus report of group 4 of the joint EFP/ORCA workshop on the boundaries between caries and periodontal diseases. J Clin Periodontol 2017; 44: 135-144.

17. Van Dijken JW, Hasselrot L. A prospective 15-year evaluation of extensive dentin- enamer-bonded pressed ceramic coverages. Dent Mater 2010; 26: 929-939.

18. Fradeani $M, D^{\prime}$ Amelio $M$, Redemagni $M$, Corrado $M$. 5-year follow-up with Procera all-ceramic crowns. Quin- 
tessence Int 2005; 36: 105-113.

19. Lindunger A, Smedberg Jl. A retrospective study of the prosthodontic management of patients with amelogenesis imperfecta. Int J Prosthodont 2005; 18: 189-194.

20. Naert I, Donk AVD, Beckers L. Precision of fit and clinical evaluation of all-ceramic full restorations followed between 0.5 and 5 years. J Oral Rehabil. 2005; 32: 51-57.

21. Beuer F, Stimmelmayr M, Gernet W, Edelhoff D, Güh JF, Naumann M. Prospective study of zirconia-based restorations: 3-year clinical results. Quintessence Int 2010; 41: 631-637.

22. Pelaez J, Cogolludo PG, Serrano B, Serrano JF, Suarez MJ. A four-year prospective clinical evaluation of zirconia and metal-ceramic posterior fixed dental prostheses. Int J Prosthodont 2012; 25: 451-458.

23. Rinke S, Gersdorff N, Lange K, Roediger M. Prospective evaluation of zirconia posterior fixed partial dentures; 7 year clinical results. Int J Prosthodont 2013; 26: 167-71.

24. Sulaiman TA, Abdulmajeed AA, Donovan TE, Cooper LF, Walter R. Fracture rate of monolithic zirconia restorations up to 5 years: A dental laboratory survey. J Prosthet Dent 2016; 116: 436-439.

25. Bömicke W, Rammelsberg P, Stober T, Schmitter M. Short-Term Prospective Clinical Evaluation of Monolithic and Partially Veneered Zirconia Single Crowns. J Esthet Restor Dent 2017; 29: 22-30.

26. Bankoğlu Güngör $M$, Karakoca Nemli $S$, Çağlar $A, A y-$ dın C, Yılmaz H. Clinical study on the success of posterior monolithic zirconia crowns and fixed dental prostheses: preliminary report Acta Odontol Turc 2017; 34: 104-108.

27. Konstantinidis I, Trikka D, Gasparatos S, Mitsias ME. Clinical Outcomes of Monolithic Zirconia Crowns with CAD/CAM Technology. A 1-Year Follow-Up Prospective Clinical Study of 65 Patients. Int J Environ Res Public Health 2018; 1215(11).

28. Worni A, Katsoulis J, Kolgeci L, Worni M, Mericske-Stern R. Monolithic zirconia reconstructions supported by teeth and implants: 1- to 3-year results of a case series. Quintessence Int. 2017;48:459-467.

29. Sarıkaya I, Hayran Y. Effects of dynamic aging on the wear and fracture strength of monolithic zirconia restorations. BMC Oral Health. 2018;18(1):146.

30. Marquillier T, Doméjean S, Le Clerc J, Chemla F, Gritsch $\mathrm{K}$, et al. The use of FDI criteria in clinical trials on direct dental restorations: A scoping review. J Dent. 2018;68:1-9. 31. Raigrodski AJ, Chiche GJ, Potiket N, Hochstedler JL, Mohammed SE, et al. The efficacy of posterior three-unit zirconium-oxide-based ceramic fixed partial dental prostheses: a prospective clinical pilot study. J Prosthet Dent. 2006;96(4):237-44.

32. Pihlaja J. Treatment Outcome of Zirconia Single Crowns and Fixed Dental Prostheses. University of Oulu. Doktora Tezi, 2016, Finlandiya (Danışman: Prof. Dr. A Ra- ustia).

33. Pjetursson BE, Sailer I, Makarov NA, Zwahlen M, Thoma DS. All-ceramic or metal-ceramic tooth-supported fixed dental prostheses (FDPs)? A systematic review of the survival and complication rates. Part II: Multiple-unit FDPs. Dent Mater. 2015;31:624-639.

34. Sailer I, Makarov NA, Thoma DS, Zwahlen M, Pjetursson BE. All-ceramic or metalceramic tooth-supported fixed dental prostheses (FDPs) A systematic review of the survival and complication rates. Part I: Single crowns (SCs). Dent Mater. 2015;31(6):603-623.

35. Schmitter M, Mueller D, Rues S. Chipping behaviour of all-ceramic crowns with zirconia framework and CAD/ CAM manufactured veneer. J Dent. 2012;40:154-162.

36. Tartaglia GM, Sidoti E, Sforza C. Seven-year prospective clinical study on zirconia-based single crowns and fixed dental prostheses. Clin Oral Investig. 2015;19(5):11371145.

37. Lawson NC, Bansal R, Burgess JO. Wear, strength, modulus and hardness of CAD/CAM restorative materials. Dent Mater. 2016;32:275-283.

38. Tang Z, Zhao X, Wang H, Liu B. Clinical evaluation of monolithic zirconia crowns for posterior teeth restorations. Medicine (Baltimore). 2019;98(40):17385. 